\title{
EL IMAGINARIO ORIENTAL DE ALBERTI Y NERUDA
}

M. Teresa Hernández Fernández

U.N.E.D.

Es un hecho evidente el auge actual en los estudios literarios de la Psicocrítica, reverdecimiento que, sobre todo en la crítica francesa, empieza a convencionalizarse terminológicamente como Poética de lo imaginario. Sus raíces bien notorias y proclamadas se asientan en el Psicoanálisis crítico basado en Freud y Jung. La condición eminentemente postbachelardiana de sus cultivadores actuales más representativos se hace sentir en la fisonomía de sus objetos de reflexión: análisis de mitos sobre todo en la obra de Gilbert Durand ${ }^{1}$, y especulación sobre la espacialidad fantástica de las construcciones novelescas en el monumental estudio sobre la obra de Julio Verne debido a Simone Vierne ${ }^{2}$ y sobre el espacio de representación imaginaria en el poema en Jean Burgos y A. Garcia Berrio ${ }^{3}$. En mi opinión precisamente lo que de más prometedor ofrece esta reciente iniciativa en el plano de la Crítica literaria es que se han revalidado muchos de sus atractivos y brillantes postulados metodológicos mediante análisis rigurosos extensos y sistemáticos.

El conjunto de propuestas críticas que introduce el planteamiento de principio para el estudio del funcionamiento de la imaginación en la cocreación, entre autor y lector, del texto artístico como producto imaginario de intercambio y comunicación psicológica, ofrece muy variadas y amplias perspectivas, una de las cuales es la que se refiere a la construcción de representaciones imaginarias sobre conjuntos muy complejos de elementos de realidad, necesariamente elaborados y convencionalizados bajo la interferencia de la carga de representaciones imaginarias que peculiarizan la visión de ese contemplador-construcción. La historia es el espacio privilegiado para esta modulación de las construcciones imaginarias como arquetipos culturales. Cuando hablamos comúnmente de una edad histórica o de

1 Cfr. G. Durand, Estructuras antropológicas de lo imaginario, Madrid, Taurus, 1984.

2 Cfr. S. Vierne, Jules Verne et le roman iniciatique, Paris, Ed. de Cirac, 1973; además de esta tesis es útil la consulta de Roman, rite, iniciation, Grenoble, Presses Universitaires, 1973.

3 Cfr. J. Burgos, Pour une Poétique de l'imaginaire, París, Seuil, 1983. A. García Berrio, La construcción imaginaria en Cántico de Jorge Guillén, Limoges, Trames, 1985. 
un estilo artístico del pasado -barroco, renacimiento, ilustración- lo hacemos inevitablemente en términos de construcción imaginaria, de nuestra propia visión mediatizada y distante, muchas veces apasionada. Pero como con estos aspectos temporales de la construcción imaginaria, ocurre también $-\mathrm{y}$ privilegiadamente- con los espaciales.

Singularmente en la representación artística del exotismo local y geográfico, con su bien conocida carga de responsabilidad en la configuración de la literatura y el arte de todos los tiempos, juegan un papel determinante estos componentes de la elaboración fantástica e imaginaria. Y ello es válido tanto para las curiosidades antiguas, la del famoso rinoceronte de Durero, como para las fantasías futuristas de Piranesi, Verne u Orwell. La novela bizantina de viajes y aventuras, y tantos hitos gloriosos de la caballeresca y sentimental, sustentan algunos de sus mejores atractivos mediante sus propuestas de construcciones imaginativas de espacios, de fantasías sobre lugares remotos y legendarios, en los antípodas de la objetividad puntual de la crónica. El exotismo oriental para el arte europeo desde el romanticismo ha trazado influencias decisivas y famosas desde Gauguin o Van Gogh a Rimbaud y Eluard. El oriente distante y desconocido funciona en estos casos sobre todo como una ilusión fantástica, constituyéndose después como una propuesta imaginaria empapada siempre de prejuicios culturales y de las peculiaridades de la imaginación personal de los creadores.

En este marco de referencias metodológicas trato ahora de abordar la muestra de las peculiaridades de representación imaginaria oriental en dos brillantísimos poetas hispánicos viajeros casi contemporáneos por China: Pablo Neruda y Rafael Alberti. Y precisamente en las peculiaridades que definen la constitución de sus respectivas representaciones imaginarias del universo geográfico, humano y cultural de China, se delinean con nitidez aleccionadora y ejemplar tantas no inmediatas pistas y facetas hondas de sus respectivas personalidades poéticas.

Durante la década de los cincuenta abordan dos poetas de habla hispana una etapa viajera de sus vidas que los trae desde América hasta Europa, por Portugal, Praga y Moscú, y cuyo destino final será la legendaria China. El origen de estos viajes poéticos era el mismo: formaban parte del programa de actividades culturales planteado por la Internacional Comunista. El resultado viene dado en las páginas de Las uvas y el viento, en las que se incluyen los recuerdos del viaje a China de Neruda de 1954, y las de La primavera de los pueblos de Alberti, correspondientes al viaje realizado entre 1955 y 1957. Los dos libros constituyen una inestimable prueba del bagaje poético de los viajeros y de las claves líricas más profundas y permanentes que depara una construcción imaginaria del Oriente, enmarcadas, claro está, en las circunstancias ideológicas especialísimas de su visita a China.

Pese al paralelismo externo de estas situaciones, Alberti y Neruda inician y culminan su andadura de modo muy distinto, como veremos. Ya desde el comienzo del viaje y en los primeros contactos con los países comunis- 
tas europeos el planteamiento imaginario de cada poeta se centra en dos compromisos diferentes: Neruda fija en Checoslovaquia, en la gigantesca figura de Fucik, todo el paisaje humano de esta etapa, mientras Alberti menudea en la evocación de la ciudad de Praga y su río - agua bajo los puentes donde perderse a soñar-. En Polonia sin embargo la sombra del poeta Mickiewiez es para Alberti el aliento humano que anima su descripción de las llanuras polacas, cuando Neruda se limita a enumerar en este caso intrascendentemente sus estaciones viajeras. La muestra más interesante, con todo, de esa primera fase del viaje en ambos poetas es la expresión lírica de la estancia moscovita de Alberti: el tono de feliz y hasta descarado panegírico a la Unión Soviética, su proclamación de sentirse como en casa propia, habiendo dejado atrás las tinieblas inseguras de la sociedad occidental, resuena ya desde el título en el segundo de los poemas albertianos, «iQué absoluto descanso...!»:

"iQué absoluto descanso llegar a ti de nuevo $y$ dormir sin angustias en la noche sintiendo que el sueño sigue siendo tranquilamente el sueño!n.

Breve respiro, trivial sentimiento de reposo, pero no exento de justificación, ya que el programa de viaje habia sido agotador, con lo que Moscú significaba, aún en este aspecto puramente turístico, un alto reparador para su vida de errante exiliado.

Junto a tales razones de naturaleza política, interesa constatar en qué grado el contagio del aura sentimental y estética del proyecto fantástico, las razones de tipo artístico que traducen una concepción imaginaria, prevalecen frente a la inocultable monotonía y reiteración de jornadas, etapas, motivos y visiones, producidas por coyunturas políticas semejantes en estos libros de viaje de Alberti y Neruda. La situación de entendimiento ideológico con China, que propició la asimilación de su brillante caso revolucionario y de reconstrucción nacional por parte de la Internacional Comunista, no sólo permitía, sino que incluso hacía urgente, entre 1954 y 1957, la publicación de textos tan prestigiosos como los de Neruda y Alberti. La propaganda la recuperación pacífica de los pueblos socialistas, que comparece en la literatura de consigna de estos poetas comunistas tras el período de sangrienta exaltación revolucionaria, viene a encuadrar totalmente las razones ideológicas de estos libros de viaje. Pero tampoco el contenido artístico es ni mucho menos desdeñable. Alberti y Neruda son dos poetas en plenitud, experimentados en la totalidad de los registros temáticos y sentimentales im-

4 Cfr. Rafael Alberti, «La primavera de los pueblos», en Poesias Completas, Buenos Aires, Losada, 1961. Los poemas relativos a su estancia en China se agrupan bajo el título general de Sonrie China, entre las páginas 1068 y 1108 . En lo sucesivo citaremos sólo la abreviatura P.C. 
plicados en la obra, tanto los ideológicos como los estríctamente líricos. Añádase, además, que obras como éstas de ensoñación fantástica de culturas remotas no dejaban de ofrecer, en el plano de la construcción imaginaria, perfiles muy favorables a sus mejores capacidades poéticas, Ilegando a remontarse en ocasiones a verdaderas alturas de sensibilidad elegiaca en el imaginario decadentista de sus ensoñaciones líricas y pudiendo fundir a un tiempo, privilegiadamente, la obligada carga de contenido doctrinal de consigna, que alcanza en muchos momentos uno de sus más dignos niveles de inspiración.

El análisis de los indices de poemas de La primavera de los pueblos y Las uvas y el viento permite establecer la presencia de constantes temáticas comunes en Alberti y Neruda. No sólo se dan las obligadas coincidencias a propósito de monumentos como la Gran Muralla, sino que también se constata la selección de los mismos acontecimientos políticos, como las canciones a la Gran Marcha. La presencia común de sintomas muy próximos se acentúa en la aparición de símbolos y mitos idénticos -el Yangtsé, la tortuga y la serpiente,...-, o en el paralelismo estructural de la mención personal, a manera de carta o recuerdo desde China - en el caso de Alberti, el recuerdo es para el arquitecto Luis Lasa-. Otro rasgo idéntico muy significativo de convergencias imaginarias en el caso de la celebración de China por los dos poetas lo ofrece su común adhesión al filtro literario bajo el que se muestra la civilización asiática como estereotipo convencionalizado. Si Neruda es el hermano gigantesco del énfasis épico, el refinado gaditano Alberti es el recreador insuplantable de la vivencia de interiores, de la voz susurrante de los viejos artistas de la China -el poeta Ai Ts'ing o el pintor Chi Pai-Shih-.

La presencia del filtro imaginario al que aludíamos antes tamiza convenientemente en numerosos perfiles la visión fantástica oriental de Alberti y Neruda; pero será la acción de un dilatado trasfondo tópico de cultura artística lo que estructure la construcción imaginativa del mundo oriental que estos poetas trasfunden sentimentalmente a sus libros. No hay que insistir demasiado en la tradición de curiosidad exotista que desde Baudelaire y Rimbaud había llenado el interés de todos los renovadores franceses de la poesía moderna. Procedente de la misma fascinación imaginaria habría que destacar un rasgo menos notorio en apariencia, pero también interesante: la perpetuación del haiku. La difusión, velada en cualquier caso, del haiku en la literatura española contemporánea, estudiada por Pedro Aullón de Haro $^{5}$, es la prueba más lícita de esta fascinación literaria por oriente que apuntamos. Según Aullón no sólo se da la correspondencia formal más evidente del haiku con la greguería de Gómez de la Serna, o la presencia más explícita en formas del cancionero de Alberti, sino que del alcance real en la popularidad de este género se podrían testimoniar muchos ecos en los más

\footnotetext{
5 Cfr. Pedro Aullón de Haro, El haiku en España, Playor, Madrid, 1985.
} 
encumbrados momentos de la poesía española contemporánea, como en los mejores textos de Juan Ramón o García Lorca. Complementariamente, además, es preciso puntualizar que la formación del convencionalismo oriental de Alberti está más nutrida de presencias autóctonas españolas que de transferencias francesas. Incluso en el dominio más internacional y directo de las corrientes plásticas, la oleada de moda oriental, que explicaría las pinturas polinesias de Gauguin, y sobre todo la vocación a la diluida plástica china y japonesa que poblaria la figuración de ciertas etapas de Van Gogh, se hallaba ya en una persistente y depurada vocación por el arte oriental de la pintura española contemporánea, que prepararon al poeta Alberti para esta asimilación en imágenes plásticas del remoto mundo de China. Recordemos cuánto hay de conceptualización plástica del mundo y la vida en el libro del poeta gaditano. El biógrafo de Alberti Manuel Bayo ha destacado a este respecto la sintomática anécdota de un acontecimiento extraordinario en la vida artística de China, vinculado precisamente a la peripecia concreta del viaje de Alberti: el último dibujo del famoso pintor Chi-Pai-Shi, a quien Alberti dedica uno de los más bellos poemas de su libro, fue el regalo del ya centenario artista chino al poeta español. Bayo evoca, siguiendo seguramente las noticias del propio Alberti, la viva conmoción producida en las escuelas de Pekín por esta última muestra del gran pintor chino ${ }^{6}$.

La figuración oriental de Neruda es sin duda mucho más realista y fielmente objetiva, como consecuencia no sólo del predominio de su vocación de objetividad épica, sino también de su dilatada presencia como habitante en el mundo oriental. Sin esa aclimatación de hábitos en las etapas de reprẹsentación consular del poeta chileno de su amigo, Rafael Alberti sabe captar sus imágenes de China de una manera más fiel y directa. Le ayudan a ello en primer lugar esa capacidad selectiva de pintor, que le faculta para una más inmediata plasmación de las estructuras plásticas del mundo, pero también hay que explicarse este fenómeno por el sencillo hecho de su superioridad poética, que ha quedado bien fundamentada durante años a través de una obra esplendorosa.

El poeta gaditano exhibe en Sonrie China su habitual genialidad, su capacidad de transformación poética del mundo, que pasa necesariamente por las etapas previas de la fiel captación y de la asimilación personal. En las imágenes poéticas de Alberti no hay lugar, sobre todo en estos años de plenitud y maestría absolutas, para la voz debida a otros o los imaginarios interpuestos. Caracteriza el tono poético de Alberti en esta obra el ritmo entusiasta y febril de la consigna, con remedos de la marcha incontenible de la China renacida, y la grácil andadura rítmica de las imágenes y la sintaxis en las composiciones populares y festivas. Una euforia entusiasta, un sincero optimismo fuera de todo cálculo impuesto, recorre todas las composiciones de Alberti. La fascinación del nuevo mundo se difundió por las alegres ve-

${ }^{6}$ Cfr. M. Bayo, Sobre Alberti, Madrid, C.V.S. Ediciones, 1974, p. 81. 
nas poéticas del gaditano, convocando los más sinceros y animados acentos de su cantarina inspiración.

Neruda, por su parte, agrupó sus recuerdos de China en dos colecciones diferentes. La titulada El viento en el Asia, que forma parte del libro de experiencias viajeras Las uvas y el viento, publicado en Alemania en 1955, recoge los aspectos políticos propagandísticos y de consigna de la relación de Neruda con China, su voz heroica. Los aspectos líricos, los acentos más estéticos o familiares en su representación imaginaria de ese contacto, como la «Oda a la Gran Muralla en la niebla", o la "Oda a un tren en China", los segregó Neruda del libro general heroico, publicándolos en la miscelánea viajera que tituló Navegaciones y regresos. Y si el viaje de Alberti se traduce en el alegre periplo de un marinero ebrio de las hermosuras descubiertas en el Yangt sé, Neruda, en cambio, fue siempre el irónico y ambiguo diplomático paladeador de los mejores goces posibles, tras el brindis exacto e impecable.

La diferencia global más acusada entre el libro de Alberti y el de Neruda, por lo que a estructuración general del tematismo imaginario se refiere, podríamos cifrarla en la condición mucho más evidente y diáfana de libro de viaje que manifiesta la obra del poeta gaditano. Desde el ingenioso poema prologal de La primavera de los pueblos, titulado precisamente «El viaje a Europa", Alberti no titubea en ofrecernos, hasta en sus menores detalles y anécdotas, una auténtica relación desde su salida de Argentina: visiones, encuentros grandes y menudos, deslumbramientos, cansancios, trenes, aeropuertos, hoteles, están gargosamente evocados y narrados con encanto singular por Alberti. En ese mismo sentido, la presentación de Neruda de su sobrevuelo de la China en el poema inicial "Volando hacia el sol» es mucho menos rica en esos detalles anecdóticos de camino y posada, convocando sólo el recurso de la visión general «a vista de pájaro» del país como panorama.

Con Alberti viajamos por el río Amarillo, por el Yangt sé, visitamos Shangai, ascendemos a las frías y pobres tierras del Norte. Sus lagos aparecen siempre localizados y convocados precisamente por sus nombres. Tanto en el poema al "Ton Hu», o lago del Este, como el "Chin Hu», o lago del Oeste, aparece plasmada una escenografia imaginaria riente y animada, mucho más acorde con la auténtica vivencia de Alberti abigarrada y festiva. Todo canta en estos lagos albertianos "con neblinas blancas de montaña), ámbitos cercados de las coronas tejidas por los frutales de la ribera: «Flores que sonríen, niños, blandas flores, por las frescas islas y los claros bosques". Los lagos de Alberti ofrecen la cantarina sinfonía de los remos y las barcas, imagen persistente que puebla todo el paisaje de China en sus poemas:

"Cantando, los remos mueven las muchachas.

Abril es el verde patrón de las barcas"?.

${ }^{7}$ Cfr. R. Alberti, P.C., pp. 1076-77. A propósito de bellos y evocativos poemas como és- 
El tema de la Gran Marcha había sido objeto preferente de atención por parte de Alberti y de Neruda. Tal tema imponia aquí esa mímesis de ritmo acústico e imaginario que caracteriza la grandiosidad poética de Neru$\mathrm{da}^{8}$, su voz continental, los efectos de rapto y torbellino multitudinario del poeta épico chileno. Ninguno de los dos aceptó la servidumbre de la poesía política, imposición en la que apenas caían sus inspiraciones, más vivaces e irreprochablemente independientes. Es notorio el jubiloso y desentendido ejemplo de Alberti, quien no sustituía jamás la familiaridad personal de sus ritmos imaginarios, pletóricos de vitalidad, por esas obligaciones de palabrería comprometida, salvando así, aún es estos "Poemas de urgencia», la dignidad de su ejercicio poético. Por ejemplo, en el poema titulado «Por los campos y los caminos", festiva explosión de color y de musicalidad eufórica.

"Veloz, todo se afana, todo se multiplica.

Nada, por más pequeño que sea, yace inmóvil.

Mirad. Tan solamente el sol de cada aurora

levanta mil millones de manos campesinas».

No se deja ganar Alberti, como prueban estas imágenes, por el hurto del compromiso con la retórica de ocasión. Incluso es más, como ha visto agudamente a propósito de este poema Vicente Llorens, la inspiración del poeta alcanza hasta el feliz anacronismo del contagio de formas arcádicas ${ }^{10}$ :

te, ha destacado Vicente Lloréns el rasgo de pletórica alegría primaveral que impregna todo el libro de Alberti: "Es curioso observar que en los poemas a la China revolucionaria de nuestro tiempo, apenas entra en juego la historia, y que el tono combativo ha desaparecido casi por completo. Lo que domina en esa China sonriente de Alberti es una visión idílica poblada de flores y jardines... y en donde la palabra "primavera", imagen de lo nuevo y juvenil, se repite constantemente". Vicente Llorens, $R$. A. poeta social, Historia y mito, en M. Durán (ed.), Rafael Alberti. El escritor y la critica, Madrid, Taurus, 1975, pp. 297-307.

${ }_{8}$ La bibliografia estilistica sobre Neruda resiente en este aspecto de la grandiosidad de sus ritmos heroicos el desdén con que relegó al olvido toda poesía «no pura» del poeta chileno el inolvidable estudio de Amado Alonso. No obstante, él mismo se percató muy adecuadamente de la génesis estilistica de tales registros, imprescindible ya para la comprensión de obras anteriores a las propiamente heroicas. Recordemos al respecto fragmentos tan significativos como el siguiente, a propósito del contagio de liricidad rítmica y prosaismo retórico: "En cualquier momento abandonará Neruda el movimiento que él mismo se va organizando en ritmo, para agotar descriptivamente con palabras de prosa una imagen que se resiste a fijarse en otro modo". Cfr. Amado Alonso, Poesia y estilo de Pablo Neruda, Buenos Aires, Ed. Sudamericana, 1968, p. 175. Entre los contados casos que abordan el estilo épico acertadamente grandilocuente de Neruda, recordemos, aunque muy tangencial, el breve artículo de B. Belitt, "Pablo Neruda and the "gigantesque", Poetry, 80, 2 (1952), pp. 116-118. Aprecia ocasionalmente aspectos relacionados con esta modalidad del estilo de Neruda, Giuseppe Bellini, La poesia di P.N., Padova, Liviana, 1966; véase, por ejemplo, p. 54.

9 Cfr. J. Cano Ballesta, La poesia española entre pureza y revolución, Madrid, Gredos, 1971: «Nadie puede negarle fuerza, intensidad y extraordinaria calidad. Incluso cuando Alberti cae en lo vulgar y panfletario tiene formulaciones felices y golpes certeros. Esta "poesia de urgencia" ha invertido el ideal lírico de años atrás».

${ }_{10} \mathrm{Cfr}$. V. Llorens, $R$. A., poeta social, cit, califica a Alberti, acertadamente, de «poeta bucólico de la revolución", p. 307. 
"Qué vaivén! Bulle el agro. Se abren nuevos caminos

por donde se derrama la verde agricultura.

En esta nueva Arcadia ni el eco escucharia

los alternados cantos de los viejos pastores'" ${ }^{11}$.

Por eso Alberti afronta la obligada coyuntura de la evocación forzosamente efectista de la Marcha, escapa del atolladero, como a la carrera, con una mención rápida, al paso:

"Tantos fueron soldados y tantos fueron héroes de una sola bandera cuando la Larga Marcha. Mas todos son los hijos del Primero de Octubre y a todos por igual su luz los condecora”.

En cambio, al evocar el mismo símbolo, Neruda adopta una imagen esquemática y testimonial de la grandiosidad gigantesca que transfiere la muchedumbre en marcha. En su poema «El Gigante» el poeta chileno había introducido la evocación colosal como vehículo significativo de la epopeya. El gigante comparece como aquella nube en la pintura negra de Goya de la guerra, que amenaza campos y seres. Pero aquí no se trata de un gigantismo maléfico, sino tutelar: "Alto estaba el gigante midiendo paso a paso / su arroz, su pan, su tierra, su morada». Este gigante de Neruda tiene la grandiosa indiferencia de los poderosos y la providente capacidad protectora de los benévolos:

"El tranquilo gigante no contestó. Miraba las anchas tierras duras de China. Recogia con una sola mano toda la pesadumbre y la miseria, y con la otra mostraba el rojo trigo de mañanam. ${ }^{12}$.

Parecia obligado en la visita de un poeta a China tratar del encuentro con los compañeros artistas de aquel país. Comparecen no solamente la previsión imaginaria natural, sino los prejuicios favorables sobre el exotismo artístico. Alberti nos ofrece un diálogo indirecto con el libro de un poeta

11 Cfr. R. Alberti, P.C., p. 1083.

12 Cfr. P. Neruda, "Las uvas y el viento", en Obras Completas, Buenos Aires, Losada, 1967 (3.' ed.), Vol. I, pp. 723 y ss. El poema aludido en p. 760 . En lo sucesivo citaremos por la abreviación O.C. 
en su importante crónica autobiográfica articulada en su composición «Para el poeta Ai Ts'ing». Pero ese espacio estructural del libro Alberti lo había llenado ya con su delicioso poema de visita al viejo pintor Chi Pai-Shih. Es lógico, además, que la conmoción de Alberti ante la pintura china, siendo él mismo pintor de sensibilidad muy afinada, fuera mucho más sincera y efectiva que la que sólo podía experimentar por la poesía en una lengua totalmente críptica y desconocida. Quizá a este motivo se deba el que en «Un saludo para Chi Pai-Shih» haya llegado Alberti a transmitirnos los más convincentes y matizados descubrimientos del alma china para una sensibilidad occidental, precisamente a través de la delicada manera de representar las flores y el paisaje:

"Sólo por ti la rosa

suspira con más aire, es más alada.

$Y$ más fina, al volar, la mariposa.

Y la fruta, al nacer, más delicada» ${ }^{13}$.

En lírico diálogo con los poetas y pintores vivos, Alberti se pierde gozosamente en el laberinto de la contemplación. El jubiloso triunfo de la estética orilla en el olvido cualquier mención de ensangrentado compromiso. Como mucho, aquella salutación final al viejo pintor hermanándola solidariamente en el deseo de paz de todo su pueblo:
"Y asi sueñes, pintor, ya en los confines
del jardin de la paz de tu pintura, junto a tu pueblo, que en la paz madura como el árbol mejor de tus jardines".

En esta diferente situación de la visión de los poetas manifiestan, una vez más, Alberti y Neruda su doble y distanciado entendimiento de la poesía comprometida. Los mensajes del universo poético intimo y feliz de Alberti ${ }^{14}$ no corresponden al solemne rumor del mar proletario de Neruda, a su voz proteica. Comparece el tumulto radiante de las odas heroicas del poeta chileno en poemas como «El desfile» 0 «China», celebraciones del tema de la revolución y la Gran Marcha:

13 Cfr. R. Alberti, P.C., p. 1078. Solita Salinas de Marichal ha destacado este rasgo de las imágenes florales, vegetales incluso, de los poemas de China frente a la tendencia "antivegetal» de obras de Alberti como Caly canto. Imágenes directrices de los respectivos libros tanto más significativamente reveladoras si se tiene en cuenta la orientación bachelardiana que pretende mantener la autora en sus análisis de Alberti. Cfr. S. Salinas de Marichal, El mundo poético de R. A., Madrid, Gredos, 1965, p. 158.

14 Cfr. V. Llorens, R. A., poeta social, cit., p. 307. 
"Hoy otros hombres desfilaban,

sonrientes y seguros,

decididos y alegres,

pisando fuertemente la tierra liberada

de la patria más ancha»" ${ }^{15}$.

Dentro del juego de contrastes que venimos ejerciendo con los libros paralelos de Alberti y de Neruda, se asocia automáticamente el recuerdo de algunas de las composiciones más vibrantemente populares de Sonrie China. Singularmente próximo por muchos conceptos se nos presenta en el admirable poema de la "Primavera en Cheng Tu» la febril convocatoria al jubiloso banquete del poema de Alberti:

"Ha estallado en Cheng Tu la primavera.

iVenid, venidla a ver por los caminos!

iCorred a contemplar lo que antes era

el vía crucis de los campesinos!".

Un desbordamiento que se prolonga, milagrosamente:

"Hoy todo es sangre, hervor, crujiente vida, improbo, inagotable manadero

iVenid, venid a ver la acometida

de este inmenso hormiguero!" ${ }^{16}$.

Parece necesario destacar en este punto la escasa sensibilidad de Alberti en estos momentos líricos para la ternura infantil. El niño es un símbolo estético de China para el poeta, una «dulce promesa», sobre todo para sus canciones políticas. Por el contrario, en Neruda el rasgo de su permanente fidelidad a la memoria infantil, a su ternura por los pobres niños desvalidos, que empieza a manifestarse ya en los propios recuerdos de sí mismo y su infancia pasada junto a los obreros ferroviarios en el primitivo ferrocarril donde trabajara su padre, alcanza ecos sentimentales altamente significativos. Esa memoria de Neruda volverá a ejercerse en Las uvas y el viento, donde al comienzo del poema «Todo es tan simple», los niños forman con su algaraza una calurosa corte de acogida: «De mañana en la aldea / los niños y la luz

15 Cfr. P. Neruda, O.C., I., pp. 744.

16 Cfr. R. Alberti, P.C., cit., pp. 1081-82. Una precoz y en general atinada valoración del alcance imaginario de las pulsiones entusiásticas de Alberti puede seguirse en distintos lugares del libro de S. Salinas de Marichal, El mundo poético de $R$. A., cit., concretamente el estudio de ritmos de similar dinamismo en Marinero en tierra, en p. 23. 
me recibieron». El poema equivalente en el libro de Alberti, «Primero de abril» subraya jubilosamente el esplendor de la fiesta:

\author{
"Hoy, por el lago, banderas. \\ Violines y banderas. \\ Los estudiantes están \\ de fiesta. \\ Las barcas en flor repiten \\ dentro del agua sus velas".
}

Y cuando es obligada la exaltación laboriosa, regeneradora, de la nueva China, la luminosidad estética que le comunica el arte de Alberti transforma definitivamente en júbilo el rigor y el esfuerzo del trabajo. O en otras ocasiones, en aquellas evocaciones albertianas de otras tierras del norte de China, en los poemas "De Hangchow a Mukden», tierras tristes evocadas desde el fantasma imaginario personal de la Castilla tópica, donde la alegría del gaditano marítimo no fue capaz de comunicar ni una gota de animación a los hombres ni al paisaje:
"Grises las aldeas, pálido el adobe, pálidos los campos del norter.

El resurgimiento de la nueva China, libre ya del colonialismo imperialista, se convoca en los poemas de Las uvas y el viento y Sonrie China como evocación simbólica adecuada a la imaginería propagandistica comunista, no exenta sin embargo de una intensa capacidad de sugestión misteriosa, de invocación monumental a la grandeza del pasado de Oriente. Esta simbología arquetípica atribuida por Alberti y Neruda a los agresores de China es idéntica en su configuración. Por ejemplo, en la «Pequeña crónica de Mukden» de Alberti, la descripción de los invasores japoneses adopta estos términos:

"...mientras en la altura
torvos halcones oscuros
persiguen a las palomas.
Asi en Mukden los feroces
gavilanes japoneses
hicieron presa en el dulce
corazón del pueblo chino"

17 Cfr. R. Alberti, P.C., cit., p. 1098. 
Pero quizá sea en el entusiasmo vital de estos ataques anti-imperialistas de Alberti elemento directriz el ejemplo de Neruda. La fascinación heroica que traducen los argumentos capitales y los dicterios favoritos nerudianos se orientan hacia el colosal adversario americano, blanco habitual de los ataques continentales de Neruda en su Canto general.

Parece formar parte de la retórica sentimental de este tipo de libros de consigna viajera, como se desprende al menos del ejemplo de los de Alberti y Neruda, una dolorida invocación de las dificultades personales en la vida del poeta, como si éstas propiciaran el apacible remanso del descanso acogedor. El cotejo de los libros de Neruda y Alberti corrobora totalmente que estamos en presencia de una pieza insustituible en la retórica afectiva y en la estrategia propagandística de este tipo de libros. Advirtamos que en su más larga composición para el libro de China, la titulada «Para el poeta $\mathrm{Ai}$ Ts'ing", Alberti había trazado una interesantísima síntesis geográfica de su trayectoria personal militante y sobre todo literaria. Lo que sucede es que la animada exposición de Alberti le daba ocasión para realizar una de las más brillantes sintesis autobiográficas de su figura de las que disponemos, verdadero pórtico poético magistral para su Arboleda perdida.

Los episodios sangrientos y trágicos de la autobiografia ofrecida por Alberti al poeta chino transcurren en precisa prontitud:
"Los primeros disparos, el tañido
yerto de la campana de las ejecuciones
entraron en mi alcoba,
y fue en ese momento cuando bajé a la calle
$y$ entre en las barricadas y las balas
y la sangre caida
de los obreros y los estudiantes
hallé la puerta que me dio el camino
de la alegre y la dura luz que hoy
todavia me sigue iluminando" ${ }^{18}$.

Y así, naufragado el dolor en la inmensidad de las notas de entusiasmo positivo de Alberti, la obligada dimensión doliente del saludo viene reducida a una gentil entrega final, salpicada por añadidura de esperanzados matices:

"Dejo un clavel de España en tu pecho, pidiéndote

lo estreches hasta el día seguro en que mi mano

te recibirá en la tierra, todavia amarrada.

que me esperan.

18 Ibid., pp. 1103-1104. J. Luis Tejada ha destacado este rasgo de "rehumanización» nostálgico como una de las constantes que recorren la obra de Alberti desde sus primeros libros. Cfr. J. L. Tejada, R. A., entre la tradición y la vanguardia, Madrid, Gredos, 1977, p. 626. 
En El viento en el Asia de Neruda la función salutatoria de estas síntesis biográficas no viene confiada a ningún poema concreto, a diferencia de lo que sucede en Alberti, lo que no quiere decir, no obstante, que no existan incluso más frecuentemente que en Alberti doloridos alegatos biográficos diseminados por los poemas del libro. Por ejemplo, en el poema titulado "Dando una medalla a Madame Sun Yat Sen», Neruda rompe en una proclamación enfática y airada de solidaridad con China que le lleva a proclamar las miserias de su continente americano:
"Nosotros, los hombres de Latino América, conocemos a vuestros enemigos.
Nuestro continente tiene toda la riqueza, el petróleo, el cobre, el azúcar, el nitrato, el estaño, pero todo esto pertenece a nuestros enemigos, a los mismos que habéis expulsado para siempre».

Tras la indignación, la denuncia, el verso dolorido, la queja ensangrentada:
"Mientras que nuestra gente de los campos y aldeas
no tienen zapatos ni cultura, ellos han levantado, con el producto del saqueo, casas de cincuenta pisos en New York y con nuestras riquezas han fabricado las armas para esclavizar a otros pueblos".

para cerrarse todo en la salutación como reconocimiento:
"Por eso la victoria del pueblo chino es nuestra victoria.
Por eso la nueva China es amada y respetada por todos los pueblos» ${ }^{19}$.

Esa capacidad grandiosa de remontarse a las cimas de la expresión del dolor y de la dignidad humanas de Neruda, su ambición cósmica, su sabiduría para invocar alturas continentales y grandezas oceánicas que proclamen los derechos de su querella universal. Estos mismos son los acentos que re-

${ }^{19}$ Cfr. P. Neruda, O.C., I., cir., pp. 746-774. 
vivirán en total plenitud en el saludo final a China del poeta, en el inolvidable poema "Para ti las espigas» que cierra El viento en el Asia ${ }^{20}$ :

"El hombre en las Américas, inclinado en su surco,
rodeado del metal de su máquina ardiente,
el pobre de los trópicos, el valiente
minero de Bolivia, el ancho obrero
del profundo Brasil, el pastor
de la Patagonia infinita,
te miran, China Popular, te saludan
y conmigo te envian este beso en tu frenten".

El poema a la Gran Muralla es alusión tópica, referencia obligada, viñeta específica de un viaje a China. Tanto Alberti como Neruda compusieron poemas al lugar, en los que curiosamente parecen invertir en buena medida la tónica más habitual de su producción poética. Alberti aprovecha la sugerencia de la Muralla para levantar el consabido poema a la paz socialista; pero al hacerlo se ve obligado a convocar inusuales imágenes de estrépito militar, feroces encuentros y milenario rumor de sables y lanzas cruzadas, fragor indeseable para siempre alejado ya de la nueva China. El resultado poético no deja de sorprender por su capacidad evocativa y el ágil discurrir de sus imágenes. Moviéndose por tanto en terrenos tan extraños a sus hábitos normales, Alberti consigue dar prueba una vez más de que para el poeta el nivel minimo de creación pasa como poco por la dignidad.

En la nueva coyuntura, Neruda opta por un típico retrato de viajero. La Muralla china es en las Navegaciones y regresos una visión paisajística que no se despega siquiera de la circunstancia más inmediata a la visita en un dia de niebla. Exploración de experto, evocación histórica de culto turista, ni el más lejano eco de compromiso heroico, de resonancia proletaria, perturba la jornada del refinado diplomático. Con este elegantísimo poema en las manos, cabalgamos metafóricamente a lomos de la Muralla en la visión

20 En tales términos de "continentalidad" grandiosa coincido deliberadamente con la caracterización, que creo inevitablemente precisa, de Jaime Alazraki, Poética y Poesia de Pablo Neruda, Nueva York, Las Américas, 1965: «La definición de Pablo Neruda como "poeta continental" es tal vez la más exacta para caracterizar su itinerario poético", p. 13. Sobre el análisis de los símbolos con este contenido del Canto general, cfr., Frank Riess, The word and the stone, Language and imagery in Neruda's "Canto general", Oxford University Press, 1972, p. 52 .

Cfr. P. Neruda, O.C., I., cit., p. 761. Por su parte E. Chamorro ha descrito asi el origen grandioso del sentimiento de la gran marea americana de Neruda, a propósito del Canto general: «El movimiento del Canto, esa enorme ola que surge de los orígenes y avanza hacia la liberación del hombre oprimido, en una dirección milenaria y antiutópica, en una perspectiva apocalíptica». Cfr., E. Chamorro Guizardo, P.N. Naturaleza, historia y poética, Madrid, S.G.E.L., 1978, p. 189. 
imaginaria de Neruda entre la niebla: «El silencio, la lluvia, / te convirtieron en reptil de piedra» ${ }^{22}$.

Otro punto de vista muy diferente de apreciación poética entre Neruda y Alberti lo constituye la representación imaginaria del poeta andaluz de los tonos popularistas, su capacidad de aproximación y trasposición de esas imágenes y ritmos al mundo oriental. La alegría de Alberti, esa alegría primaveral -esa explosión andaluza - que Vicente Llorens ha destacado como característica fundamental, impuesta incluso sobre la emoción histórica, en la crónica china de Alberti ${ }^{23}$ se manifiesta en multitud de imágenes familiares, ritmos festivos, ágiles formas métricas de invocación vegetal y marina: "Te pensaba un tranquilo huerto de cereales /...y también, bajo el sol de los frutales, / la reina de las dulces mandarinas ${ }^{24}$.

Frente a la admirable sutileza lírica de ritmos populares y andaluces que maneja habilísimamente Alberti como juego imaginativo espontáneo y magistral, encontramos un bien marcado predominio de tonos entusiásticos y épicos en Neruda. Para este tipo de poemas de consigna, el caso de China no presenta novedades importantes en la estructura retórica más convencionalizada, como no fuera algún toque meramente circunstancial o local. Se alude en ellos con apasionado fervor a las diferentes facetas de la reconstrucción nacional china: agrícola, industrial e intelectual. A tal estructura propagandística pertenece el poema «El desfile», donde la pluralidad de estimulos verbales e imaginarios de Neruda para la convocatoria del tono heroico y de consigna alcanza niveles de muy alta inspiración ${ }^{25}$.

Mi acercamiento y contraste a las obras de los dos amigos poetas sirve tinalmente aquí, en un plano de consideración más global, para abundar en otro tipo de hipótesis sobre el destino final de esta modalidad de obras líricas. El proceso de depreciación que ha alcanzado de lleno a Las uvas y el viento de Neruda y a La primavera de los pueblos de Alberti es un testimonio más de la inoperatividad de tales frutos literarios, al menos en apariencia.

Como ha señalado Margarita Aguirre respecto al libro de $\mathrm{Neruda}^{26}$, su existencia ha pasado desapercibida para los amigos de recuentos favorables, habiendo sido sólo objeto de la crítica de los enemigos del poeta. El mismo

${ }^{22}$ Cfr. P. Neruda, O.C., II, p. 229.

23 Cfr. V. Llorens, R. A., poeta social, cit., p. 307.

24 Cfr. R. Alberti, P.C., p. 1076.

25 Cfr. P. Neruda, O.C., I., cit., pp. 744 y ss. Quisiera destacar las páginas de Mario Rodriguez Fernández, Reunión bajo las nuevas banderas, o de la conversión poética de $P$. N., en A. Flores (ed.), Aproximaciones a P. N., Barcelona, Ocnos, 1974, pp. 151-164, entre los escasos acercamientos a este registro estilístico de Neruda. Véase el contenido de alguna caracterización precisa: «El canto poético nace del afianzamiento social del yo y está destinado a exaltar los valores más propios del hombre. Al mismo tiempo la realidad determina imperiosamente la materia propia de la poesia, el canto poético no queda liberado al azar o al egoismo del hablante lírico, sino sujeto a expresar categorías del mundo sentidas como inabdicables», p. 162.

26 Cfr. Margarita Aguirre, La vida de P. N., Barcelona, Grijalbo, 1973. 
Neruda, comisionado accidentalmente por el Partido comunista para conceder una condecoración a una dama china, no parece tampoco demasiado persuadido de la grandeza poética de su tarea, cuando sabemos que simultáneamente escribía, como a hurtadillas, muchos de los poemas de Los versos del capitán ${ }^{27}$.

$\mathrm{Ni}$ el convencimiento íntimo de los poetas, ni el juego de los prejuicios literarios que llevaba a liquidar rápidamente estos libros en el examen de la obra de sus autores como unos frutos circunstanciales y de encargo, ni siquiera el mantenimiento de las condiciones y estrategias políticas, causa inmediata de estas misiones de propaganda, que se vieron prontamente cambiadas y hasta invertidas; ningún factor en suma permitió mantener una apreciación positiva para Las uvas y el viento y La primavera de los pueblos. La crítica se ha desentendido casi universalmente de las etapas chinas en la obra de Alberti ${ }^{28}$, y ya señalábamos antes el balance incluso negativo para Neruda que resultó de Las uvas y el viento. Frente a esta corriente general, antes fundada en la omisión y el olvido que en una crítica razonablemente negativa, quisiera yo destacar los sugestivos valores que aporta el mundo literario de ambos poetas en su representación y peculiarización de los elementos imaginarios de la cultura oriental, en su acomodación temporal a un espacio ajeno, exótico, que acaba funcionando como una propuesta imaginaria fantástica bellamente expresada y sólidamente planificada.

Para Neruda, cuya obra sobre China consideramos en conjunto muy inferior a la de Alberti, la experiencia de Las uvas y el viento supone una etapa imprescindible en el proceso de readaptación íntima de la imaginación y el estilo objetivos del Canto general a las Odas elementales. En lo que se refiere al lenguaje, ese mismo estado de transición ha sido captado por Morris E. Carson en una de las escasas referencias verdaderamente pertinentes dentro de la escuálida bibliografia estilística sobre la poesía no hermética de $\mathrm{Ne}$ ruda $^{29}$. Dentro de la obra de Alberti, aún sin añadir nada al desarrollo portentoso de su evolución lírica, el descubrimiento de China constituye algo más que el cumplimiento desganado de una singladura accesoria. La incorporación llena de sensibilidad del imaginario oriental por Alberti es una conquista importante que viene a enriquecer muy positivamente la expresión del universo poético del autor de Marinero en tierra. No es exagerado afirmar que, si bien sin La primavera de los pueblos, y muy singularmente sin su apartado Sonrie China, la significación global de la obra de Alberti sería sustancialmente idéntica, la delicada asimilación cumplida por el poeta del exotismo oriental constituye una tarea que no debe ser desdeñada en un balance de la poesía española del siglo XX. La fórmula que explica el éxito de

27 Cfr. E. Rodríguez Monegal, El viajero inmóvil. Introducción a P. N., Buenos Aires, Losada 1969, p. 136.

28 Entre las escasas referencias existentes hay que volver a mencionar como caso de comprensión excepcional el estudio de V. Llorens, $R$. A., poeta social, cit.

${ }^{29}$ Cfr. Morris E. Carson, P. N., regreso del caminante, Madrid, Playor, 1973, p. 105. 
la obra reside en último término, a mi juicio, en la distendida libertad con que Alberti siente su tarea china, en la sinceridad de su admiración y de su entrega a la fascinación de un universo recién descubierto y de sus gentes. Si en Neruda funciona este libro intensamente en su evolución en el cultivo de la poesía política, en Alberti establece una aportación decisiva dentro de la literatura moderna española en el proyecto de síntesis estética y asimilación fantástica del mundo y la sensibilidad orientales. 